\title{
Fire meets inland water via burned wood: and then what?
}

\author{
Pedro G. Vaz ${ }^{1,2,7}$, Eric C. Merten ${ }^{3,8}$, Dana R. Warren ${ }^{4,9}$, Kelsie Durscher ${ }^{3,10}$, Megan Tapp ${ }^{3,11}$, \\ Christopher T. Robinson ${ }^{5,12}$, Francisco C. Rego ${ }^{2,13}$, and Paulo Pinto ${ }^{6,14}$ \\ ${ }^{1}$ Department of Animal Science, University of California, Davis, California 95616 USA \\ ${ }^{2} \mathrm{CEABN}$ - Centre of Applied Ecology "Prof. Baeta Neves"/InBIO - Research Network in Biodiversity and Evolutionary Biology, \\ Institute of Agronomy, University of Lisbon, Tapada da Ajuda, 1349-017 Lisbon, Portugal \\ ${ }^{3}$ Department of Biology, Wartburg College, Waverly, Iowa 50677 USA \\ ${ }^{4}$ Department of Fisheries and Wildlife, Oregon State University, Corvallis, Oregon 97331 USA \\ ${ }^{5}$ Department of Aquatic Ecology, Eawag, 8600 Duebendorf, Switzerland and Institute of Integrative Biology, \\ ETH-Zürich, Zürich, Switzerland \\ ${ }^{6}$ Water Laboratory, Centre for Geophysics of Évora, University of Évora, Largo dos Colegiais, 7001 Évora codex, Portugal
}

\begin{abstract}
Wood is a key structural element in aquatic ecosystems. Wood provides habitat complexity, alters geomorphology, retains organic and inorganic material, promotes hyporheic flow, and acts as substrate for biofilms and invertebrates. Fire is an important disturbance promoting wood recruitment into inland waters, but most studies have focused on streams in western North America. Less is known about fire-derived wood dynamics on other continents or in lake environments. Here, we review fire effects on the recruitment, distribution, and function of in-stream wood, with emphasis on a series of studies from the Euro-Mediterranean. The amount of large wood in these streams was low and is expected to decline in the future because of wildfire. Wildfire engendered inputs of wood with low structural complexity, probably reducing habitat heterogeneity for aquatic organisms. Fire also provided wood with greater diameter than wood recruited by other means, but its longevity may be shorter because burned wood was more decayed and less anchored in the channel than unburned wood. Wood delivery processes are important because macroinvertebrate colonization differed between fire-derived wood that fell directly into the river and wood conditioned first on the forest floor. We present a case study describing wood dynamics in a lake after a wildfire in northern Minnesota, USA. In this study, wildfire created an area of lake shoreline with disproportionately more wood than areas unaffected by wildfire. In contrast to streams, burned wood was more complex than unburned wood in the lake system. One of the explanations may be greater scouring, abrasive action by stream flows, which breaks down burned wood faster than in lakes. Given the expected increase in the probability and severity of fire around the world, information in our review can be used to help manage riparian zones of streams and lakes.
\end{abstract}

Key words: large woody debris, disturbance, stream restoration, forest management, eucalyptus, cork oak, maritime pine, macroinvertebrates, community structure

Downed wood pieces in streams are key links between terrestrial and aquatic ecosystems, and fire can affect forested streams and lakes via burned wood. Opening of the forest canopy by wildfire often is accompanied by an initial flux of fire-exposed wood (Jones and Daniels 2008). The delivery of burned wood into inland waters may become more common as changing global climate and ongoing anthropogenic activities combine to increase the probability and severity of fire around the world (Moriondo et al. 2006, Flannigan et al. 2009, Moreira et al. 2011). Given wood's im- portance in water bodies (see Gregory et al. 2003), surprisingly little is known about the fate and consequences of fire-derived wood in freshwater ecosystems.

Possible effects of fire on wood in streams and lakes include alteration of wood characteristics and inputs, and the dynamics of wood transport and storage in the water body. In turn, fire-induced changes in the quantity and character of wood inputs have the potential to affect the aquatic biota and to cause shifts in ecosystem processes. Transformations in wood physical structure occur because,

E-mail addresses: ${ }^{7}$ pgvaz@ucdavis.edu, pjgvaz@isa.ulisboa.pt; ${ }^{8}$ mert0042.umn.edu; ${ }^{9}$ dana.warren@oregonstate.edu; ${ }^{10}$ kelsie.durscher@wartburg.edu; ${ }^{11}$ megan .tapp@wartburg.edu; ${ }^{12}$ robinson@eawag.ch; ${ }^{13}$ frego@isa.utl.pt; ${ }^{14}$ ppinto@uevora.pt

DOI: 10.1086/684095. Received 7 November 2014; Accepted 5 May 2015; Published online 23 September 2015.

Freshwater Science. 2015. 34(4):1468-1481. @ 2015 by The Society for Freshwater Science. 
in addition to changing wood mass, fire changes the form of wood pieces and alters postfire decomposition rates (Harmon 1992), thereby affecting the complexity and size of wood delivered to freshwaters. For example, tree boles tend to survive fire, whereas most branches are consumed in the blaze (Agee 1993). If burned wood pieces lack branches upon entering water bodies, a decrease in surface area may occur with consequences for habitat complexity for aquatic organisms (Sundbaum and Näslund 1998, Kovalenko et al. 2012). On the other hand, simple and straight wood pieces are less likely to become trapped or snagged during high flows than are irregular pieces of a similar size (Gurnell 2003). Wood size can also influence how wood affects the distribution, diversity, and abundance of organisms (Lester et al. 2009, Howson et al. 2012). Nevertheless, the specific effects of fire on the characteristics, inputs, and dynamics of wood recruited to inland waters and its repercussions for the aquatic biota remain poorly understood.

In contrast to burned wood, the biological importance of unburned wood in fresh waters is reasonably well documented. For example, Benke et al. (1984) reported that submerged wood substrates in rivers had higher insect abundance and diversity than surrounding sandy or muddy bottoms. For aquatic invertebrates, wood provides refugia, foraging, and attachment substrate at different life-cycle stages (Hoffmann and Hering 2000, Benke and Wallace 2003, Pitt and Batzer 2011, Merten et al. 2014, Molokwu et al. 2014). The nutritional value of wood is low, but several stream macroinvertebrates can ingest wood (Spänhoff et al. 2000), and a few can digest wood (Monk 1976) or the epixylic biofilm on wood surfaces. Mihuc and Minshall (1995) even found one macroinvertebrate taxon able to grow on burned organic matter (a mixture of wood and leaves). Several investigators have addressed the structural importance of wood for macroinvertebrates in streams (Wallace et al. 1995, Hilderbrand et al. 1997, Lemly and Hilderbrand 2000, Warren and Kraft 2006), including the effects of wood on flow patterns and organic matter retention (Entrekin et al. 2009, Testa et al. 2011). For fish, wood primarily provides habitat and refugia, such as pool habitat (Bilby and Bisson 1998, Berg et al. 1998, Dolloff and Warren 2003), and fish diversity and abundance is usually higher in streams with greater wood loading (Fausch and Northcote 1992, Neumann and Wildman 2002, Wright and Flecker 2004).

Studies on wood dynamics in freshwaters have been focused more on streams and rivers than lakes. In both cases, studies specifically addressing the effects of fire-derived wood on forested inland waters have been almost nonexistent until recently. Young (1994) conducted the first study on fire effects on in-stream wood, and only a few subsequent investigators have evaluated the effect of fire on wood loading to streams (Zelt and Wohl 2004, Chen et al. 2005, Arseneault et al. 2007, Jones and Daniels 2008). Published studies from beyond North America are limited, partic- ularly those documenting fire effects on habitat structure and the biota of aquatic ecosystems. Studies from different biomes are needed. To date, the work of Vaz et al. (2011, 2013a, b, 2014) in the Euro-Mediterranean region comprises the only set of studies specifically addressing the longterm effects of forest fires on stream geomorphology and functioning via burned wood. Stream ecosystem functioning includes a variety of processes, such as the production, retention, and decomposition of organic matter, or the retention and recycling of nutrients (Elosegi et al. 2010, Elosegi and Sabater 2013). To date, studies quantifying burned wood and its consequences for lentic ecosystems have not been conducted.

Here, we review fire effects on characteristics, recruitment, and distribution of large wood and their implications for aquatic ecosystems and their biota. We first introduce the topic of burned wood in streams as assessed through the literature. Second, we synthesize works regarding fire effects on in-stream wood and, thus, fluvial systems, by drawing from our studies in streams of east-central Portugal in a fire-prone area. The overall aim of these studies was to better understand the long-term effects of fire on lotic ecosystems mediated by fire-derived wood. In our review, we define long-term effects of fire as those lasting $>1 \mathrm{y}$. For these studies, the unifying hypothesis was that fire would influence the long-term geomorphology and habitat structure of streams and their biotas through its effects on stream wood. Third, we introduce the topic of wood in lakes and set the scene for identifying similarities and potential key differences in wood processes between streams and lakes. Fourth, we present a case study describing wildfire-wood dynamics in a lake after the Pagami Creek Fire in northern Minnesota, USA. The goals of the case study were to: 1) compare the physical structure and position along lake shorelines of burned and unburned wood, 2) compare the quantity of wood along burned and unburned lake shorelines, and 3) test the effect of the prevailing wind direction on the quantity of shoreline lake wood. We hypothesized that: 1) burned and unburned wood would differ in structure and position along lake shorelines, 2) the burned shoreline would have the most wood pieces/100 $\mathrm{m}$, and 3) upwind lake shorelines would have more wood than downwind shorelines. We conclude with an integrative discussion, management recommendations, and suggestions for future research.

\section{FIRE-DERIVED WOOD IN FORESTED STREAMS}

Fire can affect in-stream wood and, thus, fluvial systems through a variety of mechanisms, including changes to the characteristics of the wood itself, its stock and dynamics, and its effects on stream ecosystem functioning and the biota. These topics were considered in a series of studies (Fig. 1) in 27 streams in east-central Portugal evenly distributed among 9 burned subbasins of the Tagus River dominated by forests of cork oak (Quercus suber), eucalyptus (Eucalyptus globulus), and maritime pine (Pinus pinaster). Riparian tree species in- 


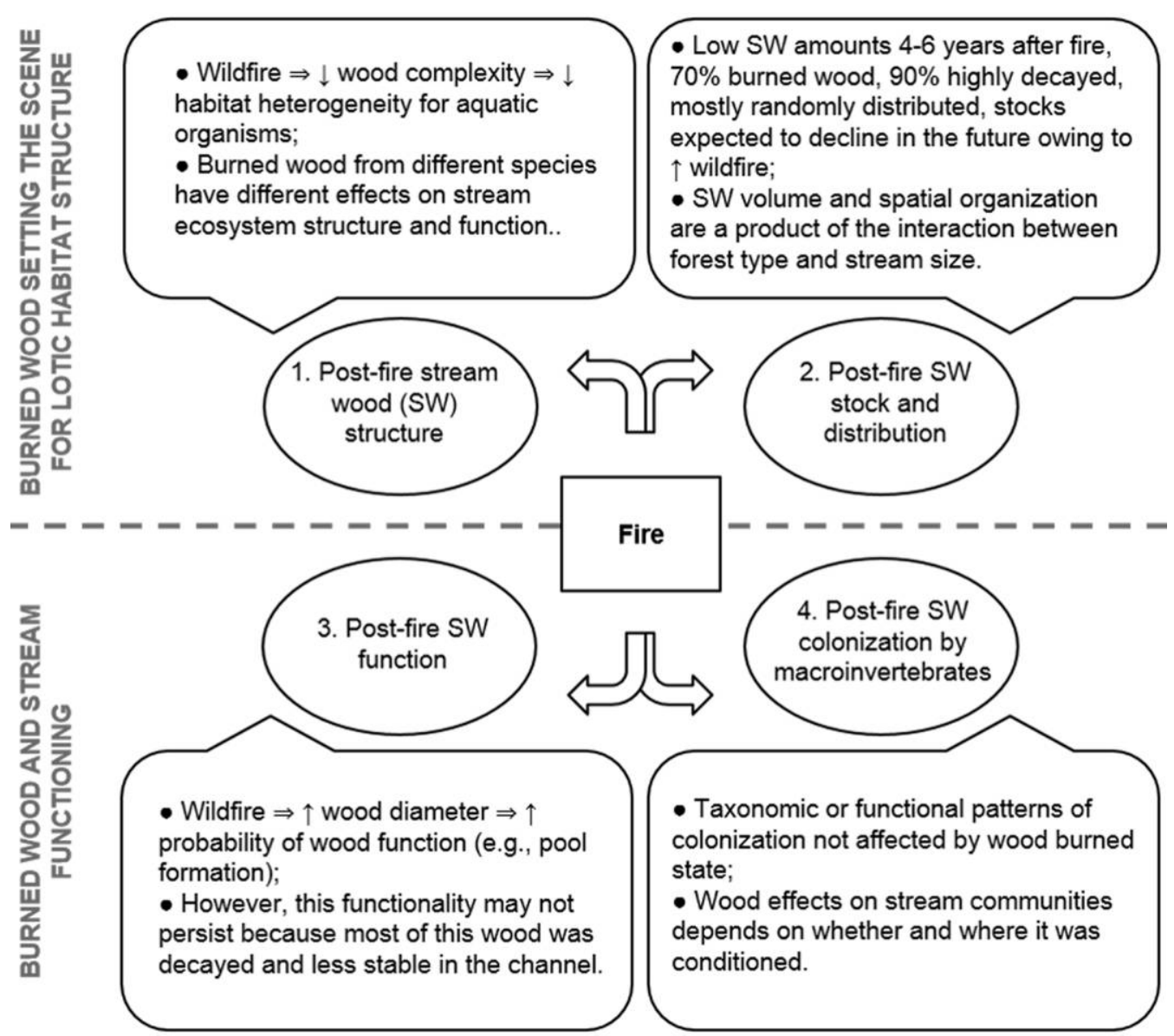

Figure 1. Conceptual model synthesizing the main findings of the set of studies in Portuguese streams (1-4: Vaz et al. 2011, 2013a, b, 2014, respectively).

cluded ash (Fraxinus angustifolia), alder (Alnus glatinosa), black poplar (Populus nigra), willow (Salix atrocinerea, Salix alba, Salix salvifolia), silver wattle (Acacia dealbata), and hawthorn (Crataegus monogyna). As is common in Mediterranean climates, watersheds of the streams had experienced wildfires (Stella et al. 2013), in this case within 4 to 6 y prior to sampling, and a burned corridor of $\geq 100 \mathrm{~m}$ was present on both sides of each stream. Vaz et al. (2011) shed light on the specific effects of fire on the physical characteristics of wood recruited to streams and found that the overall structure of stream wood was strongly influenced by wildfire. Burned stream wood was straighter, had fewer branches, was more decayed, and was thicker in diameter than unburned wood (Vaz et al. 2011). In California, USA, Bendix and Cowell (2010) found differences in the size of wood pieces that were related to tree species, results in line with those of Vaz et al. (2011). In Portugal, postfire timberproduction forests (maritime pines and eucalyptus) contributed thinner, longer, and straighter wood pieces to streams than slow-growing cork oak stands. Maritime pine wood had more rootwads and branches than other species. Pieces from cork oak and riparian species generally had a bent form, were short, and had no rootwads. Aside from the direct effects of burning, the authors noted the potential for postfire management activities to change the characteristics of wood that entered streams; e.g., sawing pieces to reduce their length or creating piles of slash along stream banks.

Fire also can change the stocks and spatial distribution of wood in streams. For example, a stream in a burned watershed in Idaho, USA, had $5 \times$ greater volume of wood than similar streams in unburned watersheds, but the wood provided little in-stream function because most was still bridging the stream 20 y postfire (Robinson et al. 2005). In contrast, postfire stocks in streams in east-central Portugal (for quantities see Vaz et al. 2013b) were similar to the lowest values published by Gregory et al. (1993) for the unburned Lymington River basin $\left(0.6-50 \mathrm{~m}^{3} / \mathrm{ha}\right)$ and by Richmond and Fausch (1995) for streams in a harvested forest in the Rocky Mountains, USA (12.0-147 $\left.\mathrm{m}^{3} / \mathrm{ha}\right)$.

In our review, we define wood organization as nonrandom spatial distribution along the stream or the lake shoreline. In the study by Vaz et al. (2013b), wood volume 
per area and in-stream spatial distribution patterns differed among forest types. For example, cork oak forests had the least wood but the most organized spatial distribution. Vaz et al. (2013b) used binned neighbor- $k$ analysis (Kraft et al. 2011) to assess wood organization (segregated, random, or aggregated) and found that streams in burned cork oak plantations had more wood-segregated areas, i.e., areas with less wood than expected by chance, than streams in other burned plantations. In these streams, the low spatial organization of wood suggested that input dynamics played a major role; i.e., fire-derived wood probably was entering the system at a rate higher than stream transport processes (producing a consequent nonrandom distribution; Kraft and Warren 2003, Kraft et al. 2011). In addition, wood spatial patterns may be related to within-channel vegetation obstructions, management actions, and fire effects (Silva et al. 2009, 2011, Vaz et al. 2013a). Spatial distribution may further vary with bank erosion or lateral transport in floodprone areas (Stella et al. 2013) and among different tree species (Bendix and Cowell 2010, Vaz et al. 2013b).

Some investigators have attempted to assess the time needed postfire for wood stocks in streams to return to prefire levels (Young 1994, Zelt and Wohl 2004, Arseneault et al. 2007, Jones and Daniels 2008). These studies clearly showed that large burned wood may remain in streams for years as a major and conspicuous legacy of fire events. For example, Vaz et al. (2013b) found that $70 \%$ of wood pieces in their study streams were burned, but decay was high for $90 \%$ of them (using decay classes adapted from Jones and Daniels 2008). In a future where fires are expected to become more common (Moriondo et al. 2006), streams could potentially be in a perpetual state of recovery. If burned wood is depleted and is replaced by fewer wood pieces from a young forest, recovering streams will have low stocks of large wood. Individual pieces of wood then may become particularly important (Rosenfeld and Huato 2003) in providing habitat for the biota and the physical framework for ecosystem processes (Elosegi et al. 2010). In addition, only a subset of wood substantially influences geomorphological, hydraulic, and ecological functions at any one time. For example, bridging pieces may be downed by fires but might not influence most stream functions until $\geq 20$ y postfire (Robinson et al. 2005).

Wood pieces can affect virtually every physical, chemical, and biological process in streams (Gregory et al. 2003, Ashkenas et al. 2004, Daniels 2006, Baillie et al. 2008, Coe et al. 2009, Merten et al. 2013). Functional large wood consists of pieces that perform $\geq 1$ observable function in the stream (Vaz et al. 2013a), such as deflecting flow, retaining sediment, armoring banks, creating debris jams, retaining organic matter, or serving as a substrate for aquatic vegetation, biofilms, invertebrates, and oviposition sites (e.g., for amphibians). The burn status of stream wood affects its size, geometry, and overall stability, and is likely to influence its effects on a stream's physical and biological condition through direct and indirect mechanisms (Everett and Ruiz 1993, Gurnell et al. 2002, Chen et al. 2008, Schneider and Winemiller 2008). For example, changes in wood size and shape can influence the degree to which wood affects the diversity and abundance of the biota, and wood stability, in turn, influences channel morphology (Jackson and Sturm 2002, Andreoli et al. 2007, Comiti et al. 2008, Lester et al. 2009). Large wood pieces have a greater longterm influence on habitat and physical processes than small pieces (Dolloff and Warren 2003). By creating wood that lacks structural complexity (no branches, straighter), wildfire probably will reduce habitat complexity and diversity for aquatic organisms (Sundbaum and Näslund 1998). Vaz et al. (2013a) summarized by noting that burned pieces were large in diameter (thus, more likely to be functional, e.g., via pool formation; Magilligan et al. 2008) but more decayed and not anchored (thus, less likely to be functional). These counter-balancing effects may explain the lack of a direct effect of watershed burn status on stream function (as defined above).

Burned wood from riparian trees may be damaged and then directly enter stream channels, or wood may fall onto the forest floor and remain there until it moves laterally into stream channels during floods or bank erosion (Bendix and Cowell 2010). Few investigators have examined the importance of these wood input processes vs wood burn status for the aquatic biota. Vaz et al. (2014) examined the influence of wood preconditioning and burning on instream colonization by macroinvertebrates. They conducted a field experiment in which burned and unburned wood pieces were conditioned for $1 \mathrm{y}$ in streams (water preconditioning) or on the forest floor (soil conditioning) before being placed into streams. Invertebrate colonization of this conditioned burned and unburned wood was compared to that on unconditioned burned and unburned wood placed directly in the stream. Contrary to expectations, patterns in invertebrate colonization did not differ substantially between burned and unburned wood. However, wood preconditioning significantly influenced macroinvertebrate colonization. Wood that entered stream channels directly attracted more opportunistic taxa (e.g., chironomids), whereas preconditioned wood had lower densities, but greater diversity, of invertebrate taxa. Further study would be valuable to explore the role of wood recruitment pathways and burn status on the stream biota.

\section{FIRE-DERIVED WOOD IN FORESTED LAKES}

Processes related to wood in lakes are similar in some respects to those in streams. Amounts of wood reflect both natural occurrences and anthropogenic influences. At local scales, human development and associated landscaping activities can dramatically reduce wood, as can direct removal of existing wood for aesthetic or recreational rea- 
sons (Jorgensen et al. 2006, Marburg et al. 2006). In more natural settings, the amount of wood in lakes can be correlated with forest stand density, which can be manipulated by forest management (Schindler and Francis 2006).

Wood provides valuable substrate for the growth of periphyton and invertebrates and may attract fish by providing habitat and attached food (Smokorowski et al. 2006). Lewis et al. (2014) found more amphipods and their invertebrate predators in a lake after than before a fire in the surrounding uplands. They did not assess wood, but wood inputs could have increased (see our case study below), and generalist amphipods might have been consuming the wood directly (Kobayashi et al. 2012) or using it as shelter from fish predators (Czarnecka et al. 2014). Other changes, such as in water chemistry, also could explain the results (Lewis et al. 2014), and tests of these possibilities would be valuable.

Processes related to wood in lakes may differ from those in streams in 2 key aspects. First, wind can certainly deliver wood to streams (e.g., Hemstad et al. 2008), but we expect that wind exposure may cause stronger responses along lakes than along streams. Large lakes have substantial fetch lengths and, when fetch $>\sim 50 \times$ tree height, winds may blow unimpeded and strike riparian trees on the downwind shore with maximum force (Markfort et al. 2010). Unlike the wind-sheltered trees along narrow streams, which tend to fall toward the stream (Sobota et al. 2006), trees on downwind shores of lakes are more likely to fall away from the water. Moreover, recruitment of wood (via wind or other mechanisms) from the upwind shores into lakes may be greater than into streams (see case study below). However, we suggest that wind-generated wood recruitment will increase with stream width, although such a relationship would be difficult to disentangle from the shifting role of bank erosion (Martin and Benda 2001). A counterargument is that trees along lakes and wider rivers may be better adapted to wind (Mitchell 2012). Aside from wind, other conditions, such as ground slope and crown asymmetry (Rentch 2010), can influence the direction of tree fall and may lend further variability to patterns of wood recruitment.

Another key difference between wood processing in lakes and streams is the fate and longevity of wood once delivered. If detached from the shoreline, wood in lakes may eventually float and accumulate along the downwind shore (Marburg et al. 2009). Thus, the spatial distribution of wood in lakes is not expected to be random (as in streams; Vaz et al. 2013b). However, regardless of transport, wood probably breaks down more slowly in lakes than in streams and may remain in place for longer periods. Over time, wood can become water logged and sink to the lake bottom where decay rates and physical abrasion are both minimal. For example, Gennaretti et al. (2014) found preserved pieces of wood that spanned multiple millennia in lakes in Quebec, Canada. Wave action may mobilize wood to some extent, but we suggest that wood in streams generally is subject to greater hydraulic forces, water-level fluctuations, and bedload abrasion, which together can lead to breakage (Merten et al. 2013) and more rapid decomposition. In temperate or colder climates, ice flows during spring may also cause major wear on wood in streams (ECM, personal observation). Conversely, the main forces of nonbiological degradation acting on wood in lakes may be from ice heave on lake surfaces. Ice heave affects only wood in shallow littoral areas and only in colder climates, but the phenomenon apparently has not been studied to date. Biological contributions may increase decay rates more in streams than lakes because of greater aeration and mixing in streams (Kretschmar et al. 2008). However, some wood may persist for millennia in slackwater areas and after burial (Hyatt and Naiman 2001, Boucher et al. 2006).

\section{FIRE-DERIVED WOOD IN FORESTED LAKE ISABELLA, MINNESOTA, USA Study area}

We studied fire-derived wood in Lake Isabella, in northern Minnesota. The study area was in the Superior National Forest, where anthropogenic effects are generally limited to sparse roads and forest management. Average temperatures for summer and winter are 19 and $-17^{\circ} \mathrm{C}$, respectively (USDA 2015). The lakes are surrounded by transitional temperate-boreal forest, and riparian vegetation was dominated by jack pine (Pinus banksiana) and paper birch (Betula papyrifera), with $\sim 10-20 \mathrm{~cm}$ diameter at breast height $(\mathrm{DBH})$.

The Pagami Creek fire originated from a lightning strike $20.9 \mathrm{~km}$ east of Ely, Minnesota, and was first detected on 18 August 2011. After a sudden drop in relative humidity and an increase in wind, the fire reached the forest canopy and began to spread quickly. The fire travelled with the prevailing wind in a southeastern direction, primarily through a remote wilderness area (Boundary Waters Canoe Area Wilderness). By the time it ended in November 2011, the burned area was $376 \mathrm{~km}^{2}$ (USDA 2012).

\section{Data collection}

We sampled wood on 6-11 August 2013 from 5 lakes in the study area: Isabella, Wilson, Silver Island, Windy, and Whitefish. Lake size varied from 137 to 509 ha (Table 1). Lake Isabella was near the center of the burned area (Fig. 2). The lakes in the unburned area were chosen from those within 5 to $20 \mathrm{~km}$ of Lake Isabella based on similarities in size and shoreline. We selected shorelines at each lake aligned with the annual prevailing wind direction; i.e., northwest to southeast.

We sampled 13 shoreline sections (2-4/lake). Within each section, we assessed wood pieces that met the follow- 
Table 1. Bathymetry, water clarity, and wood counts for the 5 study lakes in northern Minnesota. Number of wood pieces/100 $\mathrm{m}$ is shown for upwind and downwind shorelines. All wood pieces from the upwind side of Lake Isabella were burned, whereas the wood pieces from the downwind side of Lake Isabella and both sides of all other lakes were unburned.

\begin{tabular}{|c|c|c|c|c|c|c|c|c|c|}
\hline \multirow[b]{2}{*}{ Lake } & \multirow[b]{2}{*}{ Fetch $(\mathrm{m})$} & \multirow[b]{2}{*}{ Area (ha) } & \multirow{2}{*}{$\begin{array}{c}\text { Littoral } \\
\text { area (ha) }\end{array}$} & \multirow{2}{*}{$\begin{array}{l}\text { Maximum } \\
\text { depth (m) }\end{array}$} & \multirow{2}{*}{$\begin{array}{c}\text { Secchi } \\
\text { depth }(\mathrm{m})\end{array}$} & \multicolumn{2}{|c|}{ Burn status } & \multicolumn{2}{|c|}{ Pieces/100 m } \\
\hline & & & & & & Burned & Unburned & Upwind & Downwind \\
\hline Isabella & 3150 & 508.7 & 390.9 & 5.8 & 1.5 & 46 & 11 & 10.2 & 0.2 \\
\hline Silver Island & 3450 & 446.0 & 446.0 & 4.6 & 2.3 & 0 & 19 & 6.4 & 7.6 \\
\hline Whitefish & 2000 & 137.2 & 77.3 & 14.9 & 6.7 & 0 & 8 & 0.6 & 0.4 \\
\hline Wilson & 3200 & 251.7 & 93.1 & 16.2 & 5.2 & 0 & 11 & 1.0 & 1.6 \\
\hline Windy & 2500 & 182.1 & 80.5 & 11.9 & 2.3 & 0 & 27 & 0.5 & 0.4 \\
\hline
\end{tabular}

ing criteria: 1) one end resting on the bank, and the other end submerged in the water (i.e., ramping pieces, excluding fully submerged ones), 2) the entire diameter of the submerged end under water, and 3) $\geq 1 \mathrm{~m}$ of length that was $\geq 10 \mathrm{~cm}$ in diameter above or in the water. Physical mea- surements taken for each piece of wood were: total length, diameters at the center and both ends, lateral distance from the shoreline to the center of the piece, elevation of the center above or below the water surface, north-south horizontal angle relative to the water surface, orientation $\left(^{\circ}\right), \%$ wood

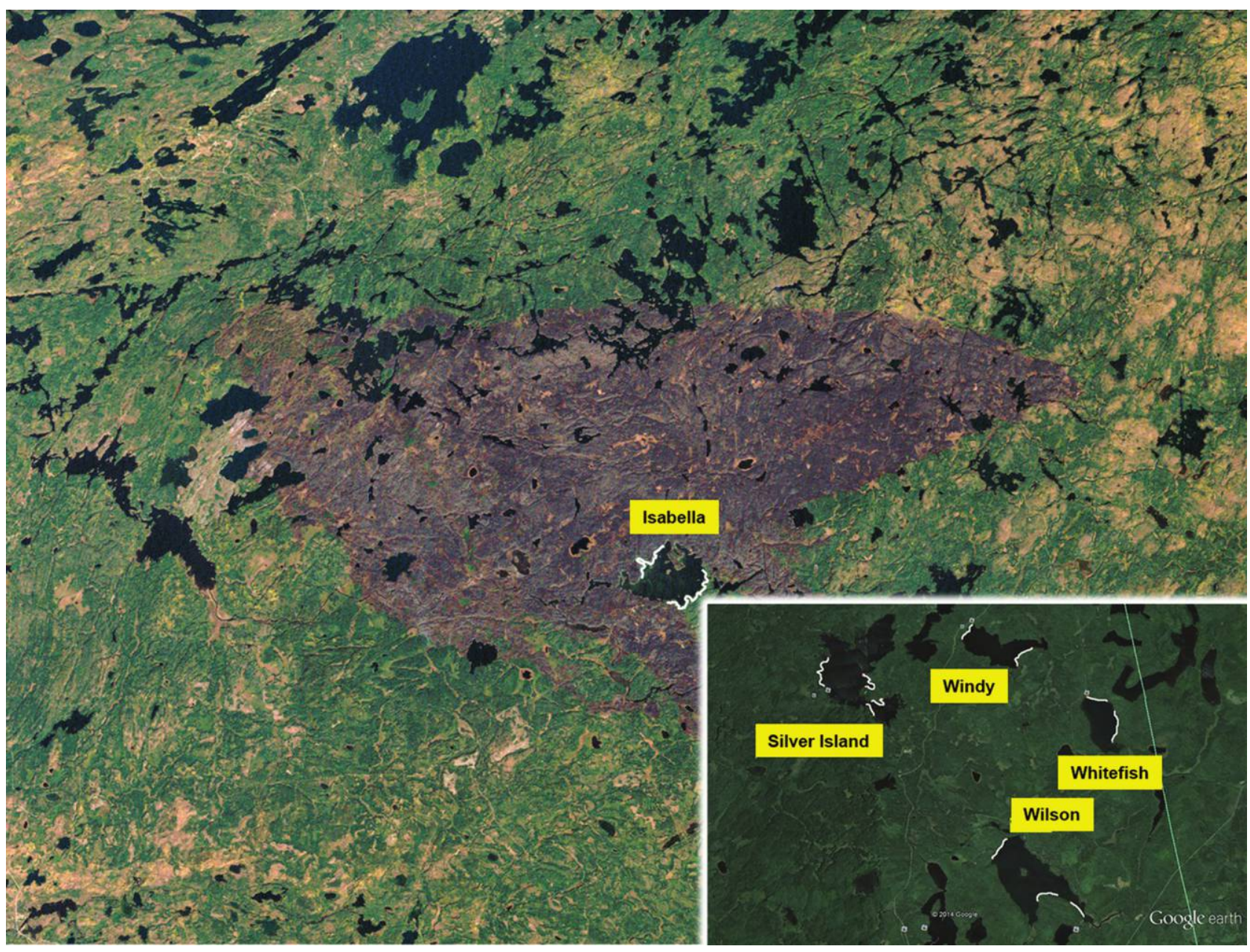

Figure 2. Area burned by the Pagami Creek fire. Inset: lakes in unburned area. Sampled shorelines are highlighted in white. The northwestern shoreline of Lake Isabella was burned, whereas the southeastern shoreline was not. The 4 lakes in the unburned area are southeast of the burned area. (http://upload.wikimedia.org/wikipedia/commons/6/63/Pagami_creek_nasa_landsat-5.jpg) 
surface that was burned (i.e., charred), \% covered with bark, and whether the piece was bent or straight, partially buried or rooted in the bank, had a rootwad, and subjectively felt soft or firm when gripped. We measured complexity of each piece of wood as described by Newbrey et al. (2005), where pieces with more branches and twigs had a higher complexity. Some measurements were later simplified into classes for the analysis: elevation $(<-30,-30$ to $30,>30 \mathrm{~cm})$, angle $\left(<10,10-20,>20^{\circ}\right)$, orientation $\left(<20,120-240,>240^{\circ}\right)$, $\%$ bark/burned $(<33,33-66,>66 \%)$, buried (yes, no), and complexity $(<20, \geq 20)$. We georeferenced the position of each piece of wood along the lake shoreline with a global positioning system (GPS; Garmin GPSMAP 62st, Sijhih, Taiwan). Using Google Earth ${ }^{\circledR}$, we digitized the sampled lake shorelines from a fixed altitude position of $914 \mathrm{~m}$ and overlaid the wood-pieces layer. We calculated the length of shorelines sampled, and recorded the aspect of the shoreline at each piece of wood. Then, we calculated the number of pieces of wood/100 $\mathrm{m}$ of shoreline for each lake.

\section{Data analysis}

We used Tukey contrasts for multiple comparisons of means to test for differences in variables between pairs of lakes with unburned shorelines (plus the unburned Lake Isabella shoreline). We investigated differences in diameter and length between burned/unburned wood pieces with 2 randomization $t$-tests (with 10,000 randomizations). We used a frequency analysis to compare patterns in counts of burned and unburned pieces across the classes of each variable in contingency tables. We then explored the pattern of standardized residuals to reveal which cross-classifications deviated the most and in what direction from expected values and, thus, contributed most to the lack of independence between burned status and the class of the variable. For lakes with unburned shorelines, we used a paired $t$-test to determine whether wood/100 m differed between upwind northwestern shorelines and downwind southeastern shorelines. We used a 1-way analysis of variance to test if the ratio upwind : downwind wood pieces/100 m differed significantly between Lake Isabella and the 4 lakes in the unburned area. All analyses were done in R (version 3.1.1, R Project for Statistical Computing, Vienna, Austria).

\section{Results}

We tallied 122 wood pieces by burn status and estimated the number of wood pieces/100 $\mathrm{m}$ for upwind and downwind shorelines for each lake (Table 1). We found significant differences between pairs of unburned lakes in aspect, \% bark, and complexity (Tukey contrasts for multiple comparisons of means; $p<0.05$ ), indicating that some local factor(s) might have influenced these variables. Whitefish Lake was involved in all significant differences, so we omitted the 8 pieces of wood sampled there from the analysis of aspect, \% bark, and complexity. Pieces of wood/100 m at lakes with unburned shorelines did not differ between upwind $(2.1 \pm 2.8 / 100 \mathrm{~m}$ [mean $\pm \mathrm{SD}])$ and downwind shorelines $(2.5 \pm 3.4 / 100 \mathrm{~m})$ shorelines $(t=-1.1, \mathrm{df}=3, p=0.33)$. The ratio of upwind:downwind wood pieces $/ 100 \mathrm{~m}$ was significantly higher for Lake Isabella than for the lakes with unburned shorelines (Lake Isabella $=51.00$, mean for lakes with unburned shorelines $=1.05 \pm 0.39 ; F=12840, p<$ 0.0001).

Burned wood differed from unburned wood in several ways (Table 2). Burned pieces of wood were significantly longer than unburned pieces (means: burned $=11.2 \mathrm{~m}$, unburned $=7.0 \mathrm{~m} ; t=-6.0, R=10,000, p<0.001$; Fig. $3 \mathrm{~A}$ ). Complexity was significantly associated with burn status (contingency table test, $X^{2}=35.1, p<0.001$; Fig. 3B). The percentage of burned wood pieces with complexity $\geq 20$ was higher than expected, and the frequency of burned wood with complexity $<20$ was lower than expected (standardized residuals; Fig. 3B). Burned wood was significantly farther from shore than unburned wood (means: burned = $3.3 \mathrm{~m}$, unburned $=2.4 \mathrm{~m} ; t=-2.2, R=10,000, p<0.001$; Fig. 4A). North-south orientation $\left(\chi^{2}=13.3, p=0.001\right.$; Fig. 4B) and shoreline aspect $\left(X^{2}=25.8, p<0.001\right.$; Fig. $\left.4 C\right)$ were significantly associated with burn status. Burned wood tended to occur more frequently between 120 and $240^{\circ}$ in both cases than expected (Fig. 4B, C).

\section{INTEGRATIVE DISCUSSION}

Our review lends support to the general hypothesis that fire can influence the long-term structure and functioning of forested lotic ecosystems. Wood can exhibit long-term changes after fires with clear consequences for streams (Nakamura and Swanson 2003). Research in east-central Portugal showed that lotic ecosystems still reflected wildfires that occurred $<10 \mathrm{y}$ before sampling and were likely to retain

Table 2. Mean $( \pm \mathrm{SD})$ characteristics or percentages of wood pieces for burned and unburned samples in lakes in northern Minnesota, USA.

\begin{tabular}{lcc}
\hline \multirow{2}{*}{\multicolumn{1}{c}{ Variable }} & \multicolumn{2}{c}{ Burn status } \\
\cline { 2 - 3 } & Burned & Unburned \\
\hline Length $(\mathrm{m})$ & $11.2 \pm 4.2$ & $7.0 \pm 3.3$ \\
Diameter $(\mathrm{cm})$ & $16.0 \pm 4.8$ & $15.9 \pm 9.9$ \\
Complexity & $74.1 \pm 57.4$ & $21.2 \pm 39.1$ \\
Rootwad & $58.7 \%$ & $38.2 \%$ \\
Bark $(\%)$ & $71.3 \pm 38.9$ & $61.4 \pm 38.0$ \\
Bent & $2.2 \%$ & $7.9 \%$ \\
Firm & $95.7 \%$ & $89.5 \%$ \\
Buried & $15.2 \%$ & $25 \%$ \\
Angle $\left({ }^{\circ}\right)$ & $10.3 \pm 5.8$ & $10.8 \pm 8.5$ \\
Aspect $\left({ }^{\circ}\right)$ & $160.5 \pm 60.1$ & $148.3 \pm 111.6$ \\
Orientation $\left({ }^{\circ}\right)$ & $156.9 \pm 64.6$ & $139.3 \pm 95.4$ \\
Lateral to shore $(\mathrm{m})$ & $3.3 \pm 2.6$ & $2.4 \pm 1.4$ \\
Elevation $(\mathrm{cm})$ & $-30.3 \pm 67.8$ & $-11.4 \pm 42.3$ \\
\hline
\end{tabular}


A

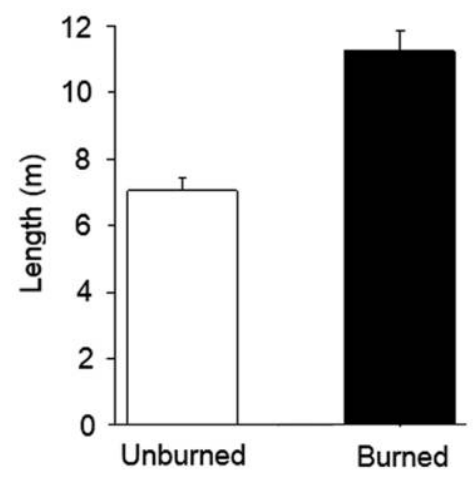

B

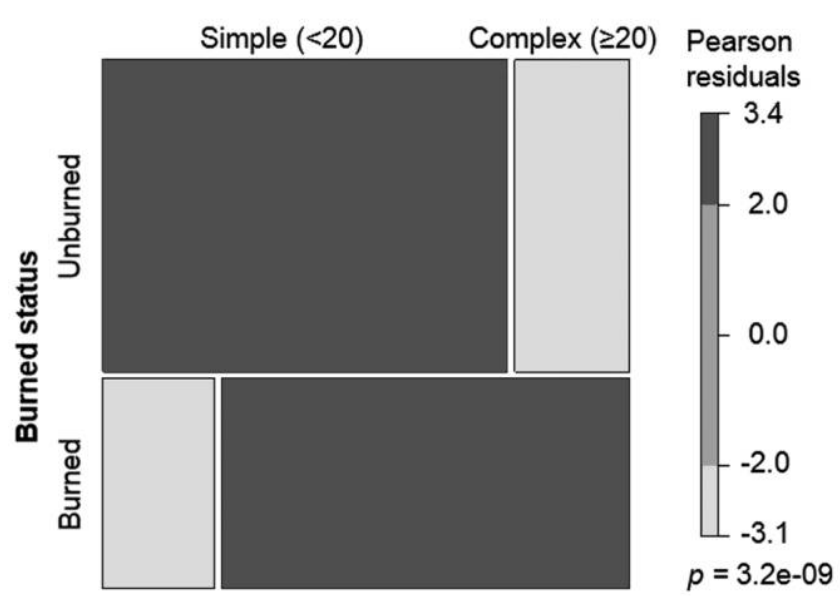

Figure 3. Relationships between burn status and lake wood characteristics. A.-Bar plot of mean (95\% confidence interval) lengths of unburned and burned wood pieces along lake shorelines. B.-Mosaic plots associating burn status of the wood pieces in the lake shorelines with branch complexity. Rectangles are proportional to observed frequencies, and shading reflects the magnitude and significance of residuals from contingency table tests.

a strong fire signal for years to come (Vaz et al. 2011, 2013b). In addition, fire led to changes in the characteristics of stream wood including its physical structure, quantity, and distribution in the stream network, potentially leading to future shifts in channel form with consequences for stream functioning. Some research has been done on woodecosystem function relationships (Lyons et al. 2005, Wallace 2007), geomorphological, hydraulic, and ecological functions (Vaz et al. 2013b), and the role of wood for stream macroinvertebrates (Vaz et al. 2014). As one might expect, including variables also influenced by biological activities shows that the response of stream ecosystem functioning to burned wood is complex (sensu Elosegi et al. 2010, Elosegi and Sabater 2013).

Our results in Lake Isabella were consistent with a pulse of whole, burned trees that entered from the shoreline of an area burned by a wildfire $<2$ y before our survey. Gen-
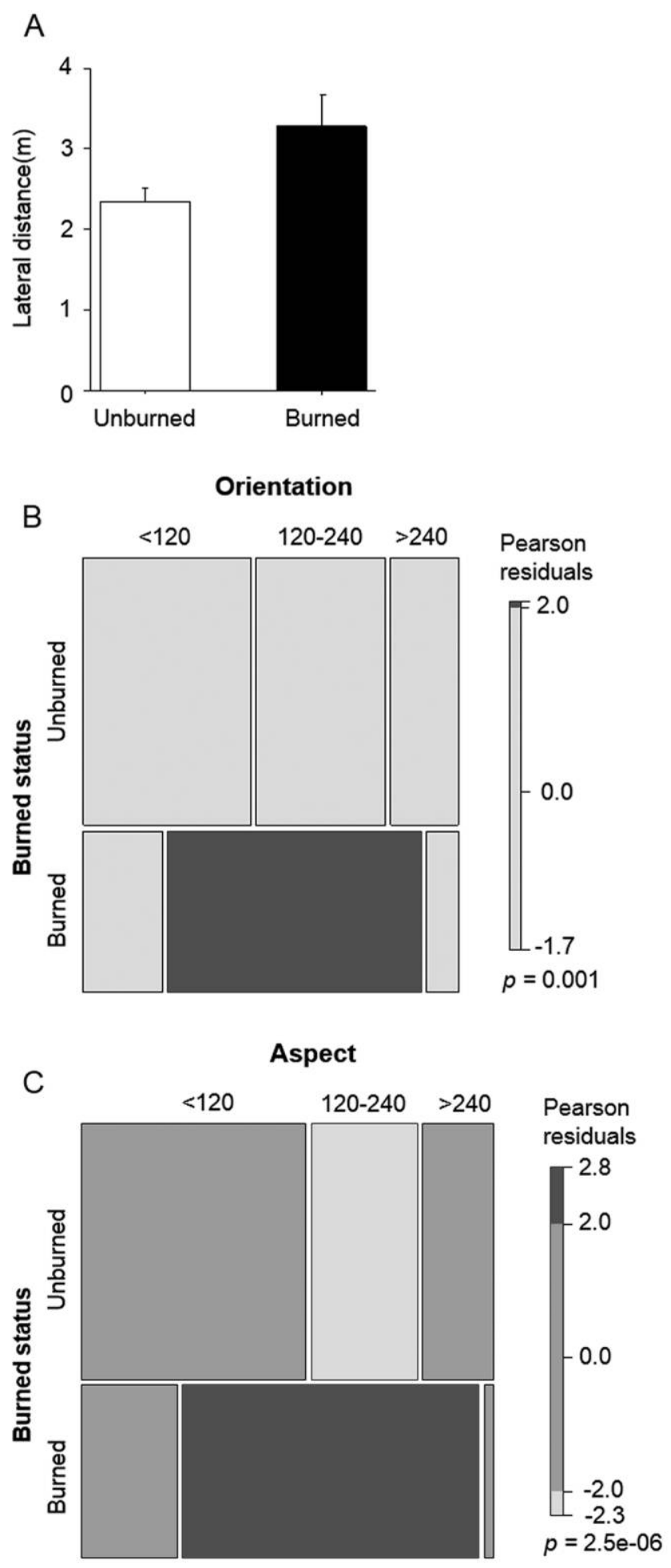

Figure 4. Relationships between burn status and positioning of lake wood. A.-Bar plot of mean (95\% confidence interval) lateral distances to the shoreline of unburned and burned wood pieces along the lake shorelines. B.-Mosaic plot associating burn status of the wood pieces along the lake shorelines with orientation. C.-Mosaic plot associating burn status of the wood pieces along the lake shorelines with shoreline aspect. Rectangles are proportional to observed frequencies and shading reflects the magnitude and significance of residuals from contingency table tests. 
naretti et al. (2014) observed that 2 of 12 wildfires affecting their study lakes in Quebec, Canada, were followed by massive wood recruitment. Our first 2 hypotheses were clearly supported; i.e., burned and unburned wood differed in structure and position along the shoreline, and the burned shoreline had more wood. Burned wood also was longer, more complex, had rootwads more often, and was at greater distances from the shore than unburned wood. Altogether, these data suggest that whole burned trees fell into the lake with much of their structure still intact. This result is important because wood pieces with greater branching complexity and roots have more surface area and may provide more habitat and resources to the aquatic ecosystem than wood with simpler structure (Sundbaum and Näslund 1998, Vaz et al. 2011). In the short term, this pulse of wood in burned lakes might be a boon to aquatic organisms. For example, wood can host a greater invertebrate biomass than open sediment by providing both substrate and a source of food (Smokorowski et al. 2006). However, in the longterm, little or no new wood may be recruited from riparian trees until the forest recovers (Guyette and Cole 1999, Gennaretti et al. 2014). Thus, as the burned wood decays, habitat and food resources for aquatic organisms may decrease. Gennaretti et al. (2014) calculated recovery times of up to $225 \mathrm{y}$ for wood recruitment patterns, depending on fire severity and stand regrowth.

In streams in east-central Portugal and the lake in Minnesota, wildfire appears to have influenced the spatial distribution of wood. The burned shoreline had a higher concentration of pieces than did the unburned shoreline, and no unburned wood was observed along the burned shoreline of Lake Isabella. The distribution of wood in inland waters that experience wildfires may be patchy if burned wood enters or is transported differently than unburned wood. For example, streams with burned watersheds may transport wood more readily than those with unburned watersheds (Young 1994, Minshall et al. 1997) because of postfire alterations in hydrology (Marcus et al. 2011). Wildfires also may change wood transport dynamics, and thus spatial organization, if burned wood itself is more or less susceptible to transport. For instance, if burned pieces tend to be larger in diameter as time passes (Vaz et al. 2011), they will be transported less readily (Merten et al. 2010), but this discrepancy may be short-lived depending on an increased tendency to break if they are brittle (Merten et al. 2013) or may be counteracted by buoyancy if burned pieces have lower density. Contrary to our expectations, wood recruitment in unburned lakes in Minnesota showed no evidence of upwind/downwind differences. This finding calls into question whether wind recruitment is more important in lakes than streams. More work is needed to test this idea.

Patterns in size and structural complexity of burned wood differed between streams in east-central Portugal and lakes in Minnesota. In contrast to the pattern in streams, burned wood in Lake Isabella was structurally more complex than unburned wood. At least 2 explanations might account for the differing results. First, the results support our expectation that the abrasive action of flow on wood breakdown appears to be greater in streams than lakes because hydraulic forces, water-level fluctuations, bedload abrasion, and ice flows are greater in streams. Burned wood may be physically weaker and more brittle than unburned wood and, thus, more susceptible to breakdown from physical processes. Second, the streams were sampled 6 y after their watersheds burned, whereas the lake was sampled $2 \mathrm{y}$ after the shoreline burned. The longer time period, combined with more active processes of physical breakdown, may explain why burned wood in the lake tended to be more complex than the burned wood in the streams.

\section{Management and conservation implications}

With or without wildfire, the critical role of wood in aquatic ecosystems makes it particularly important for management and conservation efforts. Differing values are placed on wood by various riparian stakeholders, so developing management plans around large wood can became contentious, and the success of any practice will be limited by the sociocultural framework, legislation, and historical context. Large wood is beneficial for ecological functions, but riverscapes with wood are sometimes perceived as less aesthetically pleasing, more dangerous for recreation, and in need of more improvement than riverscapes without wood (Piégay et al. 2005, Gregory 2006, Wyzga et al. 2009). In some cases, public concerns regarding wood may be warranted, especially in situations where infrastructure, such as bridges or culverts, may be threatened and human life put at risk by transported wood. In Minnesota and elsewhere, stream restoration sometimes involves removing wood because it threatens human-installed habitat structures, such as bank hides for trout. However, we suggest that infrastructure should be designed to pass natural sediment and wood loads as well as water. Large, accommodating infrastructure (i.e., large culverts or wide bridges) is likely to be more costly than small ones, but the extra cost may be mitigated to some extent by an associated decrease in maintenance costs (e.g., no more annual removal of retained wood) and risk to human life. Economic analyses on this subject would be valuable.

Many streams and lakes have been deprived of their natural wood stocks and loadings as human populations increase (Petts and Welcomme 2003). In Portugal, even though few people live around small streams and lakes in rural areas, current national legislation requires owners of land, including beds and banks of inland waters, to clean and clear the waterways of wood (Vaz et al. 2013b). In contrast, the European water framework directive (WFD) requires "good conditions" that are "not far from natural conditions" 
for streams throughout Europe. Clearly, stream wood plays an important role in meeting the intent of this policy, and authorities seek good management practices to meet the WFD, particularly when attention is drawn to water bodies after wildfires.

Removal of large wood from streams and lakes after wildfire can negatively affect stream ecosystem structure and functioning. For example, in central Portugal, in-stream large wood is not abundant, but it is important for the morphology and habitat structure of these lotic ecosystems. Removing burned wood from these streams means removing most of this valuable resource, rather than a small part of the total wood, with probable ecological repercussions. Wood inputs may be elevated shortly after wildfire because of tree mortality (Harmon et al. 1986, Benda and Sias 2003), but inputs are low during the extended postfire period of regrowth (Minshall et al. 1989). The end result is that removed wood may not be replaced for decades, and even in the best case, it will be replaced by smaller pieces (e.g., from recovering trees). Smaller pieces have less influence on bedload or sediment retention, bank armoring, and debris jams (Vaz et al. 2013a). Removing burned wood from streams also may be unnecessary because burned wood decays quickly and has less longevity than unburned wood (Vaz et al. 2013b). Removal of detached wood pieces also should be avoided in small intermittent or temporary streams, such as those in some cork oak forests where large wood is less abundant. In such streams, small wood may provide the only refugia (e.g., pools) for the biota during low flows (Robson et al. 2013). On the other hand, the suggestion by Vaz et al. (2013a) that bridging wood pieces are less functional, at least until they break, aligns well with safety and navigability concerns because this wood could be removed without ecological cost when balancing safety vs ecosystem concerns.

Another major recommendation is that practitioners should consider leaving fire-derived wood on stream and lake banks or on floodplains. The wood on the forest floor may remain there until it moves laterally into streams or lakes during floods. Our research in central Portugal clearly demonstrated that wood entering the stream after some time on the forest floor was colonized by macroinvertebrates differently than wood that entered the channel directly and that wood conditioned on the forest floor supported aquatic communities with greater diversity (Vaz et al. 2014). In addition, although large fire-derived wood lying near a stream usually deteriorates rapidly (Vaz et al. 2011), for a time it contributes to bank stability and sediment retention (Jones and Daniels 2008, Jones et al. 2011). However, a word of caution should be given in the case of small streams. Within the years for which we collected data in east-central Portugal, we observed the recruitment of large piles of burned wood compiled by humans into streams on several occasions, especially in cork oak agrosystems (e.g., slash from branch pruning for rehabilitation of burned trees). When combined with within-channel vegetation obstructions, these wood jams soon caused undesirable channel cutting. Under these circumstances, when channel form dictates an extreme spate risk, removal of longer stream wood pieces may be necessary in managed systems. Similarly, although they may interfere with lateral delivery of downed wood from the floodplain, postfire structures, such as sediment traps to disrupt overland flow and reduce erosion, may be necessary in highly managed systems (Beschta et al. 2004).

An important finding of our research in central Portugal was that downed stream wood, even after burning, still retains the species-specific physical architecture of the living trees, and tree species could not be pooled in terms of their effects on stream ecosystem structure and function or in-stream wood movement (Vaz et al. 2011). Furthermore, wood function in streams is not simply a matter of wood size, but also a function of longevity indicators, such as anchoring and decay status (Vaz et al 2013a). These conclusions are important when considering restoration projects adding natural and potentially mobile wood intended to emulate natural conditions. Overall, practitioners installing wood to streams should consider adding pieces $\sim 3 \times$ the channel width in length, with wide diameter and rootwads, and anchored but not bridging the channel. Wood previously conditioned on the forest floor does have value as potential stream wood and should be considered for addition together with freshly cut wood (Vaz et al. 2013a). In operations aimed at increasing stream hydraulic and habitat complexity, managers should avoid inputs of large wood with simple structure (e.g., eucalyptus).

Recovery of riparian areas and, thus, streams from wildfires ultimately depends on regrowth of forest stands. Dependence on regrowth may be particularly strong for wood inputs, which may be depressed for decades following wildfires (Guyette and Cole 1999, Gennaretti et al. 2014). Management activities, such as protecting surviving trees and replanting native trees, may act to expedite recovery, whereas livestock grazing or postfire logging may have the opposite effect (Beschta et al. 2004).

\section{RESEARCH DIRECTIONS}

We have highlighted key findings regarding effects of fire on aquatic ecosystems via burned wood, but many knowledge gaps still exist and several hypotheses should be tested (Table 3). A number of questions remain, in particular regarding the persistence of fire-derived wood (items 1 and 2 in Table 3). A broader regional perspective is needed (item 3 in Table 3 ) because the few studies relating to fire effects on wood in aquatic ecosystems were conducted in western North America. The work by Vaz and others in the Euro-Mediterranean region and the case study here from lakes in the mid-western USA expand this scope, but a 
Table 3. Recommendations of future research directions.

Research directions

1. The spatiotemporal dimension of postfire wood dynamics should be explicitly included in investigations of aquatic ecosystems. Key knowledge gaps remain regarding the recovery rate of aquatic ecosystems after fire. Studies quantifying inputs of burned wood and changes in wood characteristics (e.g., complexity), location, position in the channel, decay, geomorphic and biological functions over time would help to meet this need.

2. Processes determining the longevity of burned wood may differ from those of unburned wood. The role of ice and other factors on breakage should be examined, along with possible differences in the mobility of burned wood.

3. A clear causal relationship among patterns of wood loading in inland waters over time, wildfire characteristics, and upland and riparian forest context must be considered across different regions. Variables considered should include the type (surface or crown) and severity and intensity of fire, tree species resistance to fire, the age and size of trees, and the time since the previous fire.

4. Tests of the hypothesis that macroinvertebrate community composition will shift over time on burned vs unburned stream wood (Vaz et al. 2014) would bridge an important gap.

5. Burned and unburned wood should be tested for differences in nutrients and epixylic biofilms after conditioning in inland waters. This would strengthen the findings of Vaz et al. (2014).

6. The use of burned wood by fish should be studied. Wood primarily provides habitat and refuge for fish, so fire-driven changes in wood complexity might affect habitat structure for fish.

7. Studies involving pairwise comparisons of wood characteristics and dynamics in burned and unburned systems are rare and would be welcomed.

clearer understanding of regional influences on fire effects is needed. Last, more work explicitly evaluating the function of burned wood relative to unburned wood, such as the initial and long-term effects of fire-derived wood on stream invertebrates and fish, would be valuable (items 4-7 in Table 3). We observed differences between burned and unburned wood in our assessment of stream wood function $<6 \mathrm{y}$ after recruitment. However, the role of wood may change over time, and few investigators have assessed how long-term wood dynamics and functions are affected by the characteristics of or time since fire. This area of research warrants exploration to build our knowledge of aquatic ecosystem function and the effects of increasingly common large-scale disturbance events on stream ecosystems and their management.

\section{ACKNOWLEDGEMENTS}

Financial support by the Portuguese Foundation for Science and Technology (SFRH/BD/45490/2008 and PEst-OE/AGR/UI0520/ 2011) to PV is gratefully acknowledged. We thank the Dias family (Isidro, Elisa, Susana) for logistic support in Portugal. We thank the US Department of Agriculture Forest Service and Wartburg College for funding and materials to assist with sampling Lake Isabella. We also thank Therin Bradshaw and Jeremy Corbett for their assistance in data collection, and Jason Butcher for logistical support. Comments from guest editor Scott D. Cooper and 2 anonymous referees helped improve the manuscript.

\section{LITERATURE CITED}

Agee, J. K. 1993. Fire ecology of Pacific Northwest forests. Island Press, Covelo, Washington.
Andreoli, A., F. Comiti, and M. A. Lenzi. 2007. Characteristics, distribution and geomorphic role of large woody debris in a mountain stream of the Chilean Andes. Earth Surface Processes and Landforms 32:1675-1692.

Arseneault, D., E. Boucher, and E. Bouchon. 2007. Asynchronous forest-stream coupling in a fire prone boreal landscape: insights from woody debris. Journal of Ecology 95:789-801.

Ashkenas, L. R., S. J. Johnson, S. V. Gregory, J. L. Tank, and W. M. Wollheim. 2004. A stable isotope tracer study of nitrogen uptake and transformation in an old-growth forest stream. Ecology 85:1725-1739.

Baillie, B. R., L. G. Garrett, and A. W. Evanson. 2008. Spatial distribution and influence of large woody debris in an oldgrowth forest river system, New Zealand. Forest Ecology and Management 256:20-27.

Benda, L. E., and J. C. Sias. 2003. A quantitative framework for evaluating the mass balance of instream organic debris. Forest Ecology and Management 172:1-16.

Bendix, J., and C. M. Cowell. 2010. Fire, floods and woody debris: interactions between biotic and geomorphic processes. Geomorphology 116:297-304.

Benke, A. C., T. C. Vanarsdall, D. M. Gillespie, and F. K. Parrish. 1984. Invertebrate productivity in a sub-tropical blackwater river: the importance of habitat and life-history. Ecological Monographs 54:25-63.

Benke, A. C., and J. B. Wallace. 2003. Influence of wood on invertebrate communities in streams and rivers. Pages 149-177 in S. V. Gregory, K. L. Boyer, A. M. Gurnell (editors). The ecology and management of wood in world rivers. American Fisheries Society, Bethesda, Maryland.

Berg, N., A. Carlson, and D. Azuma. 1998. Function and dynamics of woody debris in stream reaches in the central Sierra Nevada, California. Canadian Journal of Fisheries and Aquatic Sciences 55:1807-1820. 
Beschta, R. L., J. J. Rhodes, J. B. Kauffman, R. E. Gresswell, G. W. Minshall, J. R. Karr, D. A. Perry, F. R. Hauer, C. A. Frissell. 2004. Postfire management on forested public lands of the western United States. Conservation Biology 18:957-967.

Bilby, R. E., and P. A. Bisson. 1998. Function and distribution of large woody debris. Pages 324-346 in R. J. Naiman and R. E. Bilby (editors). River ecology and management: lessons from the Pacific coastal ecoregion. Springer-Verlag, New York.

Boucher, É., D. Arseneault, and B. Hétu. 2006. Late Holocene development of a floodplain along a small meandering stream, northern Québec, Canada. Geomorphology 80:267-281.

Chen, X., X. Wei, and R. Scherer. 2005. Influence of wildfire and harvest on biomass, carbon pool, and decomposition of large woody debris in forested streams of southern interior British Columbia. Forest Ecology and Management 208:101-114.

Chen, X., X. Wei, R. Scherer, and D. Hogan. 2008. Effects of large woody debris on surface structure and aquatic habitat in forested streams, southern interior British Columbia, Canada. River Research and Applications 24:862-875.

Coe, H. J., P. M. Kiffney, G. R. Pess, K. K. Kloehn, and M. L. McHenry. 2009. Periphyton and invertebrate response to wood placement in large Pacific coastal rivers. River Research and Applications 25:1025-1035.

Comiti, F., A. Andreoli, L. Mao, and M. A. Lenzi. 2008. Wood storage in three mountain streams of the Southern Andes and its hydro-morphological effects. Earth Surface Processes and Landforms 33:244-262.

Czarnecka, M., F. Pilotto, and M. T. Pusch. 2014. Is coarse woody debris in lakes a refuge or a trap for benthic invertebrates exposed to fish predation? Freshwater Biology 59:2400-2412.

Daniels, M. D. 2006. Distribution and dynamics of large woody debris and organic matter in a low-energy meandering stream. Geomorphology 77:286-298.

Dolloff, C. A., and M. L. Warren. 2003. Fish relationships with large wood in small streams. Pages 179-193 in S. V. Gregory, K. L. Boyer, and A. M. Gurnell (editors). The ecology and management of wood in world rivers. American Fisheries Society, Bethesda, Maryland.

Elosegi, A., J. Díez, and M. Mutz. 2010. Effects of hydromorphological integrity on biodiversity and functioning of river ecosystems. Hydrobiologia 657:199-215.

Elosegi, A., and S. Sabater. 2013. Effects of hydromorphological impacts on river ecosystem functioning: a review and suggestions for assessing ecological impacts. Hydrobiologia 712:129143.

Entrekin, S. A., J. L. Tank, E. J. Rosi-Marshall, T. J. Hoellein, and G. A. Lamberti. 2009. Response of secondary production by macroinvertebrates to large wood addition in three Michigan streams. Freshwater Biology 54:1741-1758.

Everett, R. A., and G. M. Ruiz. 1993. Coarse woody debris as a refuge from predation in aquatic communities: an experimental test. Oecologia (Berlin) 93:475-486.

Fausch, K. D., and T. G. Northcote. 1992. Large woody debris and salmonid habitat in a small coastal British Columbia stream. Canadian Journal of Fisheries and Aquatic Sciences 49:682693.

Flannigan, M. D., M. A. Krawchuk, W. J. de Groot, B. M. Wotton, and L. M. Gowman. 2009. Implications of changing climate for global wildland fire. International Journal of Wildland Fire 18:483-507.
Gennaretti, F., D. Arseneault, and Y. Bégin. 2014. Millennial stocks and fluxes of large woody debris in lakes of the North American taiga. Journal of Ecology 102:367-380.

Gregory, K. J. 2006. The human role in changing river channels. Geomorphology 79:172-191.

Gregory, K. J., R. J. Davis, and S. Tooth. 1993. Spatial distribution of coarse woody debris dams in the Lymington Basin, Hampshire, UK. Geomorphology 6:207-224.

Gregory, S. V., K. L. Boyer, and A. M. Gurnell. 2003. The ecology and management of wood in world rivers. American Fisheries Society, Bethesda, Maryland.

Gurnell, A. M. 2003. Wood storage and mobility. Pages 75-91 in S. V. Gregory, K. L. Boyer, and A. M. Gurnell (editors). The ecology and management of wood in world rivers. American Fisheries Society, Bethesda, Maryland.

Gurnell, A. M., H. Piégay, F. J. Swanson, and S. V. Gregory. 2002. Large wood and fluvial processes. Freshwater Biology 47: 601-619.

Guyette, R. P., and W. G. Cole. 1999. Age characteristics of coarse woody debris (Pinus strobus) in a lake littoral zone. Canadian Journal of Fisheries and Aquatic Sciences 56:496-505.

Harmon, M. E. 1992. Fire influences on coarse woody debris. Pages 13-14 in Fire in Pacific Northwest ecosystems: exploring emerging issues. Oregon State University, Corvallis, Oregon.

Harmon, M. E., J. F. Franklin, F. J. Swanson, P. Sollins, S. V. Gregory, J. D. Lattin, N. H. Anderson, S. P. Cline, N. G. Aumen, J. R. Sedell, G. W. Lienkaemper, K. Cromack, K. W. Cummins, A. MacFadyen, and E. D. Ford. 1986. Ecology of coarse woody debris in temperate ecosystems. Advances in Ecological Research 15:133-302.

Hemstad, N. A., E. C. Merten, and R. M. Newman. 2008. Effects of riparian forest thinning by two types of mechanical harvest on stream fish and habitat in northern Minnesota. Canadian Journal of Forest Research 38:247-256.

Hilderbrand, R. H., A. D. Lemly, C. A. Dolloff, and K. L. Harpster. 1997. Effects of large woody debris placement on stream channels and benthic macroinvertebrates. Canadian Journal of Fisheries and Aquatic Sciences 54:931-939.

Hoffmann, A., and D. Hering. 2000. Wood-associated macroinvertebrate fauna in central European streams. International Review of Hydrobiology 85:25-48.

Howson, T. J., B. J. Robson, T. G. Matthews, and B. D. Mitchell. 2012. Size and quantity of woody debris affects fish assemblages in a sediment-disturbed lowland river. Ecological Engineering 40:144-152.

Hyatt, T. L., and R. J. Naiman. 2001. The residence time of large woody debris in the Queets River, Washington, USA. Ecological Applications 11:191-202.

Jackson, C. R., and C. A. Sturm. 2002. Woody debris and channel morphology in first- and second-order forested channels in Washington's coast ranges. Water Resources Research 38: 1117-1191.

Jones, T. A., and L. D. Daniels. 2008. Dynamics of large woody debris in small streams disturbed by the 2001 Dogrib fire in the Alberta foothills. Forest Ecology and Management 256: 1751-1759.

Jones, T. A., L. D. Daniels, and S. R. Powell. 2011. Abundance and function of large woody debris in small, headwater streams in the Rocky Mountain foothills of Alberta, Canada. River Research and Applications 27:297-311. 
Jorgensen, B. S., D. Nowacek, R. C. Stedman, K. Brasier, and D. Long. 2006. People in a forested lake district. Pages 214-235 in J. J. Magnuson, T. K. Kratz, and B. J. Benson (editors). Longterm dynamics of lakes in the landscape: long-term ecological research on north temperate lakes. Oxford University Press, New York.

Kobayashi, H., Y. Hatada, T. Tsubouchi, T. Nagahama, and H. Takami. 2012. The hadal amphipod Hirondellea gigas possessing a unique cellulase for digesting wooden debris buried in the deepest seafloor. PLoS ONE 7:e42727.

Kovalenko, K. E., S. M. Thomaz, and D. M. Warfe. 2012. Habitat complexity: approaches and future directions. Hydrobiologia 685:1-17.

Kraft, C. E., and D. R. Warren. 2003. Development of spatial pattern in large woody debris and debris dams in streams. Geomorphology 51:127-139.

Kraft, C. E., D. R. Warren, and W. S. Keeton. 2011. Identifying the spatial pattern of wood distribution in northeastern North American streams. Geomorphology 135:1-7.

Kretschmar, E. I., J. Gelbrich, H. Militz, and N. Lamersdorf. 2008. Studying bacterial wood decay under low oxygen conditions-results of microcosm experiments. International Biodeterioration and Biodegradation 61:69-84.

Lemly, A. D., and R. H. Hilderbrand. 2000. Influence of large woody debris on stream insect communities and benthic detritus. Hydrobiologia 421:179-185.

Lester, R. E., W. Wright, M. Jones-Lennon, and P. Rayment. 2009. Large versus small wood in streams: the effect of wood dimension on macroinvertebrate communities. Fundamental and Applied Limnology 174:339-351.

Lewis, T. L., M. S. Lindberg, J. A. Schmutz, and M. R. Bertram. 2014. Multi-trophic resilience of boreal lake ecosystems to forest fires. Ecology 95:1253-1263.

Lyons, K. G., C. A. Brigham, B. H. Traut, and M. W. Schwartz. 2005. Rare species and ecosystem functioning. Conservation Biology 19:1019-1024.

Magilligan, F. J., K. H. Nislow, G. B. Fisher, J. Wright, G. Mackey, and M. Laser. 2008. The geomorphic function and characteristics of large woody debris in low gradient rivers, coastal Maine, U.S.A. Geomorphology 97:467-482.

Marburg, A. E., S. B. Bassak, T. K. Kratz, and M. G. Turner. 2009. The demography of coarse wood in north temperate lakes. Freshwater Biology 54:1110-1119.

Marburg, A. E., M. G. Turner, and T. K. Kratz. 2006. Natural and anthropogenic variation in coarse wood among and within lakes. Journal of Ecology 94:558-568.

Marcus, W. A., J. Rasmussen, and M. A. Fonstad. 2011. Response of the fluvial wood system to fire and floods in northern Yellowstone. Annals of the Association of American Geographers 101:21-44.

Markfort, C. D., A. L. S. Perez, J. W. Thill, D. A. Jaster, F. PortéAgel, and H. G. Stefan. 2010. Wind sheltering of a lake by a tree canopy or bluff topography. Water Resources Research 46:W03530.

Martin, D. J., and L. E. Benda. 2001. Patterns of instream wood recruitment and transport at the watershed scale. Transactions of the American Fisheries Society 130:940-958.

Merten, E., J. Finlay, L. Johnson, R. Newman, H. Stefan, and B. Vondracek. 2010. Factors influencing wood mobilization in streams. Water Resources Research 46:W10514.
Merten, E. C., P. G. Vaz, J. A. Decker-Fritz, J. C. Finlay, and H. G. Stefan. 2013. Relative importance of transport, breakage, and decay as processes depleting large wood from streams. Geomorphology 190:40-47.

Merten, E. C., Z. R. Snobl, and T. A. Wellnitz. 2014. Microhabitat influences on insect emergence. Aquatic Sciences: Research Across Boundaries 76:165-172.

Mihuc, T. B., and G. W. Minshall. 1995. Trophic generalists vs. trophic specialists: implications for food web dynamics in post-fire streams. Ecology 76:2361-2372.

Minshall, G. W., J. T. Brock, and J. D. Varley. 1989. Wildfires and Yellowstone's stream ecosystems. BioScience 39:707-715.

Minshall, G. W., C. T. Robinson, and D. E. Lawrence. 1997. Postfire responses of lotic ecosystems in Yellowstone National Park, USA. Canadian Journal of Fisheries and Aquatic Sciences 54:2509-2525.

Mitchell, S. J. 2012. Wind as a natural disturbance agent in forests: a synthesis. Forestry 86:147-157.

Molokwu, N. D., P. G. Vaz, T. Bradshaw, A. Blake, C. Henessey, and E. C. Merten. 2014. Effects of substrate on the benthic macroinvertebrate community: an experimental approach. Ecological Engineering 73:109-114.

Monk, D. C. 1976. The distribution of cellulase in freshwater invertebrates of different feeding habits. Freshwater Biology 6:471-475.

Moreira, F., O. Viedma, M. Arianoutsou, T. Curt, N. Koutsias, E. Rigolot, A. Barbati, P. Corona, P. G. Vaz, G. Xanthopoulos, F. Mouillot, and E. Bilgili. 2011. Landscape-wildfire interactions in southern Europe: implications for landscape management. Journal of Environmental Management 92:2389-2402.

Moriondo, M., P. Good, R. Durao, M. Bindi, C. Giannakopoulos, and J. Corte-Real. 2006. Potential impact of climate change on fire risk in the Mediterranean area. Climate Research 31: 85-95.

Nakamura, F., and F. J. Swanson. 2003. Dynamics of wood in rivers in the context of ecological disturbance. Pages 279297 in S. V. Gregory, K. L. Boyer, and A. M. Gurnell (editors). The ecology and management of wood in world rivers. American Fisheries Society, Bethesda, Maryland.

Neumann, R. M., and T. L. Wildman. 2002. Relationships between trout habitat use and woody debris in two southern New England streams. Ecology of Freshwater Fish 11:240-250.

Newbrey, M. G., M. A. Bozek, M. J. Jennings, and J. E. Cook. 2005. Branching complexity and morphological characteristics of coarse woody structure as lacustrine fish habitat. Canadian Journal of Fisheries and Aquatic Sciences 62:21102123.

Petts, G., and R. Welcomme. 2003. Rivers and wood: a human dimension. Pages 421-431 in S. V. Gregory, K. L. Boyer, and A. M. Gurnell (editors). The ecology and management of wood in world rivers. American Fisheries Society, Bethesda, Maryland.

Piégay, H., K. J. Gregory, V. Bondarev, A. Chin, N. Dahlstrom, A. Elosegi, S. V. Gregory, V. Joshi, M. Mutz, M. Rinaldi, B. Wyzga, and J. Zawiejska. 2005. Public perception as a barrier to introducing wood in rivers for restoration purposes. Environmental Management 36:665-674.

Pitt, D. B., and D. P. Batzer. 2011. Woody debris as a resource for aquatic macroinvertebrates in stream and river habitats of the southeastern United States: a review. Pages 1-6 in 
Proceedings of the 2011 Georgia Water Resources Conference. University of Georgia, Athens, Georgia.

Rentch, J. S. 2010. Relationship between treefall direction, slopeaspect, and wind in eight old-growth oak stands in the Central Hardwood Forest, U.S.A. Journal of the Torrey Botanical Society 137:391-400.

Richmond, A. D., and K. D. Fausch. 1995. Characteristics and function of large woody debris in subalpine Rocky Mountain streams in northern Colorado. Canadian Journal of Fisheries and Aquatic Sciences 52:1789-1802.

Robinson, C. T., U. Uehlinger, G. W. Minshall. 2005. Functional characteristics of wilderness streams twenty years following wildfire. Western North American Naturalist 65:1-10.

Robson, B., F. Chester, B. Mitchell, and T. Matthews. 2013. Disturbance and the role of refuges in mediterranean climate streams. Hydrobiologia 719:77-91.

Rosenfeld, J. S., and L. Huato. 2003. Relationship between large woody debris characteristics and pool formation in small coastal British Columbia streams. North American Journal of Fisheries Management 23:928-938.

Schindler, D. E., and T. B. Francis. 2006. Degradation of littoral habitats by residential development: woody debris in lakes of the Pacific Northwest and Midwest, United States. Ambio 35:274-280.

Schneider, K., and K. Winemiller. 2008. Structural complexity of woody debris patches influences fish and macroinvertebrate species richness in a temperate floodplain-river system. Hydrobiologia 610:235-244.

Silva, J. S., F. Moreira, P. G. Vaz, F. Catry, and P. GodinhoFerreira. 2009. Assessing the relative fire proneness of different forest types in Portugal. Plant Biosystems 143:597-608.

Silva, J. S., P. G. Vaz, F. Moreira, F. Catry, and F. C. Rego. 2011. Wildfires as a major driver of landscape dynamics in three fire-prone areas of Portugal. Landscape and Urban Planning 101:349-358.

Smokorowski, K. E., T. C. Pratt, W. G. Cole, L. J. McEachern, and E. C. Mallory. 2006. Effects on periphyton and macroinvertebrates from removal of submerged wood in three Ontario lakes. Canadian Journal of Fisheries and Aquatic Sciences 63:2038-2049.

Sobota, D. J., S. V. Gregory, and J. Van Sickle. 2006. Riparian tree fall directionality and modeling large wood recruitment to streams. Canadian Journal of Forest Research 36:1243-1254.

Spänhoff, B., C. Alecke, and E. I. Meyer. 2000. Colonization of submerged twigs and branches of different wood genera by aquatic macroinvertebrates. International Review of Hydrobiology 85:49-66.

Stella, J., P. Rodríguez-González, S. Dufour, and J. Bendix. 2013. Riparian vegetation research in Mediterranean-climate regions: common patterns, ecological processes, and considerations for management. Hydrobiologia 719:291-315.

Sundbaum, K., and I. Näslund. 1998. Effects of woody debris on the growth and behaviour of brown trout in experimental stream channels. Canadian Journal of Zoology 76:56-61.
Testa, S., F. D. Shields, and C. M. Cooper. 2011. Macroinvertebrate response to stream restoration by large wood addition. Ecohydrology 4:631-643.

USDA (US Department of Agriculture Forest Service). 2012. Pagami Creek wildfire. Superior National Forest, US Department of Agriculture Forest Service, Duluth, Minnesota. (Available from: http://www.fs.usda.gov/detail/superior/home/?cid =stelprdb5341928)

USDA (US Department of Agriculture Forest Service). 2015. Nature and science. Superior National Forest, US Department of Agriculture Forest Service, Duluth, Minnesota. (Available from http://www.fs.usda.gov/main/superior/learning/nature -science)

Vaz, P. G., S. Dias, P. Pinto, E. C. Merten, C. T. Robinson, D. R. Warren, and F. C. Rego. 2014. Effects of burn status and conditioning on colonization of wood by stream macroinvertebrates. Freshwater Science 33:832-846.

Vaz, P. G., E. C. Merten, D. R. Warren, C. T. Robinson, P. Pinto, and F. C. Rego. 2013a. Which stream wood becomes functional following wildfires? Ecological Engineering 54: $82-89$.

Vaz, P. G., D. R. Warren, E. C. Merten, C. T. Robinson, P. Pinto, and F. C. Rego. 2013b. Effects of forest type and stream size on volume and distribution of stream wood: legacies of wildfire in a Euro-Mediterranean context. Freshwater Science 32:126-141.

Vaz, P. G., D. R. Warren, P. Pinto, E. C. Merten, C. T. Robinson, and F. C. Rego. 2011. Tree type and forest management effects on the structure of stream wood following wildfires. Forest Ecology and Management 262:561-570.

Wallace, J. B., J. R. Webster, and J. L. Meyer. 1995. Influence of $\log$ additions on physical and biotic characteristics of a mountain stream. Canadian Journal of Fisheries and Aquatic Sciences 52:2120-2137.

Wallace, K. J. 2007. Classification of ecosystem services: problems and solutions. Biological Conservation 139:235-246.

Warren, D., and C. Kraft. 2006. Invertebrate community and stream substrate responses to woody debris removal from an ice storm-impacted stream system, NY USA. Hydrobiologia 568:477-488.

Wright, J. P., and A. S. Flecker. 2004. Deforesting the riverscape: the effects of wood on fish diversity in a Venezuelan piedmont stream. Biological Conservation 120:439-447.

Wyzga, B., J. Zawiejska, and Y. F. Le Lay. 2009. Influence of academic education on the perception of wood in watercourses. Journal of Environmental Management 90:587-603.

Young, M. K. 1994. Movement and characteristics of streamborne coarse woody debris in adjacent burned and undisturbed watersheds in Wyoming. Canadian Journal of Forest Research 24:1933-1938.

Zelt, R. B., and E. E. Wohl. 2004. Channel and woody debris characteristics in adjacent burned and unburned watersheds a decade after wildfire, Park County, Wyoming. Geomorphology $57: 217-233$. 